\title{
The Development of Educational Technology Policies (1996-2012) Lessons from China and the USA
}

\author{
Alnuaman A. Alamin ${ }^{1}$, Guo Shaoqing ${ }^{1} \&$ Zhang Le $^{1}$ \\ ${ }^{1}$ College of Educational Technology, Northwest Normal University, Lanzhou, China \\ Correspondence: Alnuaman A. Alamin, College of Educational Technology, Northwest Normal University, \\ Lanzhou, China. Tel: 86-152-9317-5452. E-mail: nuoman63@gmail.com
}

Received: November 1, 2014

doi:10.5539/ies.v8n6p142

\author{
Accepted: March 6, 2015 Online Published: May 28, 2015 \\ URL: http://dx.doi.org/10.5539/ies.v8n6p142
}

\begin{abstract}
This study reviews the development of educational technology macro policies in China and USA based on the historical juxtaposition approach. It shows that, despite the fact that two countries have major differences, with China officially being a socialist country, while the USA is a capitalist country; the development of educational technology policies in the two countries has displayed remarkable similarities. USA's revised educational technology plans also were used as the basis of some of Chinese educational technology policies. The study displays how the ambitions toward integrating ICT in education moved from critical issues facing elementary and secondary schools in the USA like technology literacy after 1990, to adopting a technology-based learning model that resulted in measuring of student's outcomes individually in NETP 2010. China has moved from using traditional technology in education in the early 1990 e.g. slides, projectors, films, and radio and aims at building an educational infrastructure close to the developed countries by 2020 . The study reviews briefly the development of equipping American and Chinese schools with the ICT hardware infrastructure and the educational technology standards in both countries.
\end{abstract}

Keywords: educational technology policies, educational technology standards, infrastructure

\section{Introduction}

Policy makers in one setting commonly seek information about models elsewhere, following which they may choose to imitate those models with or without adaptation. In some settings this practice has been described as "educational borrowing". For instance, during the late 1980s, the UK Secretary of Education, Kenneth Baker, made three trips to the USA to discuss student aid programmes, and made repeated references in speeches and in print to the benefits of American models (Bray, 2007). Bray also described the field of comparative education in China: the Soviet influence took its roots in the first decade of the Young People's Republic of China and only started to fade out after China adopted Western-inspired economic reform programmes in the late 1970s. Hence the modern Chinese conception of comparative education has focused on issues related to national development in a way that most comparative research does not. This is in many ways because the bulk of comparative education scholars are Western in origin, or are educated at Western institutions. For these Westernized comparative education scholars, educationfornationaldevelopmentisoftensomethingthatoccursin"developing countries" or what was formerly referred to as Third World countries in much of the development literature historically. Yet, Chinese comparative education is often more concerned with national development for China's sake, which puts a unique spin on the focus of development and the approach to development that Chinese comparative education scholars take (Bray \& Qin, 2001)

In 1991, USA launched the National Information infrastructure (NII), which was the basic step to the widespread use of ICT in education in the USA.

According to Fluckiger (1995), NII aims at building a nationwide system that will allow all Americans to take advantage of the rich resources in information. Japan, UK, Germany, France and other developed countries have followed America to implement comparable information infrastructure in their national level. NII was a proactive step for the first educational technology plan in the USA.

In the Chinese landscape, educational technology was known as "electrifying education". This name was using before 1991. Electrifying education focused on the technologies used in education at that time, such as slides, 
projectors, films, and radio. In early 1990, electrifying education was renamed as educational technology, and it then included more developed technologies such as computers and internet. Before 1996, China had paid little attention to the development of educational technology policies compared to USA. For example, one policy promulgated in 1992, focused on strengthening computer education in primary and secondary schools, and emphasised computer education in schools. That was the first time that computer education was mentioned by name in a policy, and the first time that policy emphasized using computers to assist learning in primary and secondary schools (Zou, 2011).

However, this study compares between China and the USA in terms of educational technology macro policies in the period 1996-2012. It also reviews infrastructure and educational technology standards based on an historical juxtaposition approach.

\section{Methodology}

This study used Bereday's juxtaposition step (Bereday, 1964) to compare China and the USA based on an historical qualitative juxtaposition of their national planning for ICT in education in the period1996-2012. Berday's comparative method in education contains four steps; the Juxtapostion represents the third step in his model as it shown in Figure1. The juxtaposition has been indicated as mose important step by the comparartivists as the most important step in the Berdedays model for undertaking comparative studies in education.

According to the nature of the study as a comparative educational study the discussion will review as juxtaposition between the two countries in terms of policies, infrastructure and standards.

In terms of macro-policy and implementation, the starting point was chosen according to the first ETP in both countries, while the end point was chosen based on the newest educational technology plan in China which was promulgated in 2012, while the USA's was in 2010.

The study highlights educational technology standards during the period 1998-2011. The starting point accords with the first version of standards in the USA and the end point accords with the newest version of educational technology standards in the USA. It is noteworthy that China promulgated its standards in 2004.
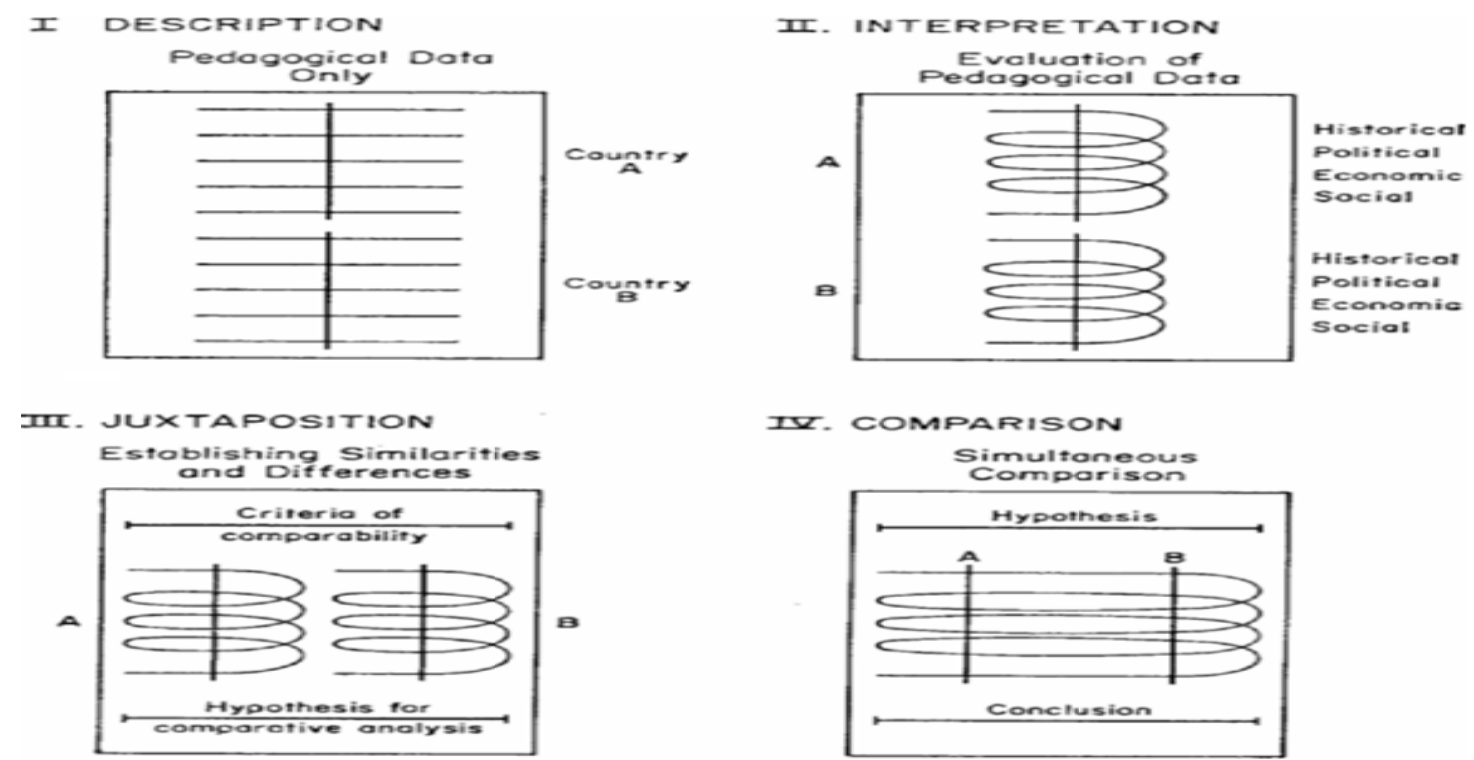

Figure 1. Bereday's model for undertaking comparative studies 
Table 1. Selective USA's plans in the period between 1996-2010

\begin{tabular}{ll}
\hline $\begin{array}{l}\text { The time of Chinese } \\
\text { plan }\end{array}$ & The name of Chinese plan \\
\hline June 1996 & $\begin{array}{l}\text { First National Educational Technology Plan } \quad \text { (NETP 1996) Getting America Students } \\
\text { Ready for the 21st Century" }\end{array}$ \\
$\begin{array}{l}\text { December 2000 } \\
\text { January 2005 }\end{array}$ & $\begin{array}{l}\text { NETP 2005 Toward A New Golden Age in American Education } \\
\text { November 2010 2010 The Model of Learning Powered by Technology-Transforming } \\
\text { American Education }\end{array}$ \\
\hline
\end{tabular}

Table 2. Selective Chinese plans in the period between 1996-2012

\begin{tabular}{ll}
\hline The time of Chinese plan & The name of Chinese plan \\
\hline December 30, 1996 & Five-Year Development Program of School Computer Education (1996-2000) \\
December 30,1998 & Action Plan for Invigorating Education Towards the 21st Century \\
July 1, 2001 & National Tenth Five-Year Plan of Education \\
September 4, 2002 & The Tenth Five-Year Plan for Educational Technology \\
February 10, 2004 & 2003-2007 Action Plan for Invigorating Education \\
May 8, 2006 & 2006-2020 National ICT Development Strategy \\
May 18, 2007 & Eleventh Five-Year Plan for National Education Development \\
March 2012 & China Educational Technology Plan 2011-2020 \\
\hline
\end{tabular}

\section{Juxtaposition}

\subsection{Educational Technology Macro Policies in USA and China 1996-2012}

By 1996, the US Department of Education recognized that educational technology is at the core of American economic growth. The plan recognized that only $4 \%$ of schools had a computer for every five students; while $9 \%$ of classrooms of these schools were connected to the internet. NETP1996 dealt with the critical issues facing elementary and secondary schools, as the education authorities were seeking to increase the effective use of technology in education at that time: training and support for the teachers, computer access and internet access for both teachers and students (NETP, 1996).

In June 1996 USA has promulgated its first educational technology plan, which was mandated by "Getting America Students Ready for the $21^{\text {st }}$ Century" NETP1996 contains four goals that should be achieved by 2000:

- All teachers in the nation will have the training and support they need to help students learn using computers and the information superhighway.

- All teachers and students will have access to modern multimedia computers in their classrooms.

- Every classroom will be connected to the information superhighway.

- Effective software and on-line learning resources will be an integral part of every school's curriculum. Computer software, video, distance learning courses, and on-line resources are expanding rapidly. (NETP, 1996)

Yumin and Ellen (2011) identified the period "1991-1995" as an initial trial period in the development of China's educational technology policies. They found that at that time, the central government began to initiate some policies that promoted the development of infrastructure and started to promote educational technology at all levels of schooling and higher education. The initial trial period appeared to have started after the year1996, when China began the implementation of various initiatives, which previously were just plans on paper. For example, the first time Chinese scholars themselves mentioned computer education in a policy was in 1991.

In December 1996, the Chinese MOE announced that it was necessary to think about how to rely on the power of educational technology to meet the challenges of the 21st century in educational technology planning. This policy represented the first step toward the reforming of China's educational technology planning show how the policy stresses at USA's NETP 1996.

Zhang (2005) posited that when China's economy began to thrive after 2003, this had a good impact on educational technology policies, and their implementation in China. Hence, the study concluded that formal educational technology planning in China started after 1996, in conjunction with the specific attention toward 
planning for educational technology in USA.

Chinese policies stressed that educational technology policies should specify the quality in education for a country, as well as be a catalyst for economic growth and human development for that it was at the centre of the Chinese policy makers' attention. For example, by 1998, the Ministry of Education (MOE) announced that technology was at the core of China's $21^{\text {st }}$ economy growth plan, and it would be the power for economic and social development in the upcoming century. Global economic competition would depend on the quality of education, science and technology and the level of innovation. Education should always occupy a strategic position in the political landscape and be considered as a priority. Modern information technology has been widely used in education and has led to profound changes in the education system. Both countries' educational policy makers stressed the power of educational technology in the $21^{\text {st }}$ century: to set the pace in leading the global economy in the USA, or enhancing economic growth in China. It was important for Chinese educational policy makers to propose educational technology policies based on the reality of economy to make progress in achievement of the goals. With both developed and developing provinces, urban and rural areas inside the developing and developed provinces presenting challenges in the implementation of educational policy, by 1996, the MOE announced that the regions with a high level of economic and cultural development that had realised the goal of nine-year compulsory education, were encouraged to achieve and exceed development goals in computer education. The relatively underdeveloped areas should be supported by the government at all levels to develop computer education based on their developmental level. All regions should consider how to make full use of limited resources to harness the best educational benefits.

By 2000, the department of education in the USA published the results of implementing the first plan. Survey results showed that about $69 \%$ of Americans support the integrating of ICT in education and they thought ICT could enhance the quality of learning; about $82 \%$ of Americans supported the USA Government's efforts at integrating ICT in the educational process, and they believed that schools should invest more in computer technology for instructional purposes; $83 \%$ of public elementary and secondary school teachers supported integrating ICT into the curriculum, but teachers themselves were not sufficiently trained to teach with technology as shown in the results of another survey.

The plan identified the year 2000 to achieve its goals, which were the transforming of the technology capabilities and improving the affordability of the technology in that time, and it became evident that there was a need to propose a new plan.

- All students and teachers will have access to information technology in their classrooms, schools, communities and homes.

- All teachers will use technology effectively to help students achieve high academic standards.

- All students will have technology and information literacy skills.

- Research and evaluation will improve the next generation of technology applications for teaching and learning.

- Digital content and networked applications will transform teaching and learning. (NETP, 2000)

The USA's second plan was a natural extension of the first plan, with regard to the accessibility of digital resources. The plan stated that resources for teaching and learning in schools and classrooms should be supported by improved quality of Internet access, and also identified broadband access as the new standard. The boom in E-learning in the USA was therefore influenced by the proposals contained in the second plan. Notably, comparing educational technology policies in developing countries such as China and India, the plan stressed that China and India were making their own multi-million dollar investments in technology for education.

NETP 2000 aimed at "Putting a World-class Education at The Fingertips of All Children", and the new Chinese Revised Plan, namely the Tenth Five-Year-Plan for E-education 2002, also discussed how to support the E-learning in the whole country: The plans were to construct the China Education Research Network (CERNET) and the China Education Broadband Satellite Transmission Network (CEBsat) to provide the basic technology foundation for the modern distance education and scientific research.

Before introducing the third plan, the USA Government involved its students in surveys it conducted in 2003. It investigated who the USA's students were and how they were thinking.

About $96 \%$ said that doing well in school was important to their live; $94 \%$ said that they planned to continue their education after high school; $88 \%$ said going to college was critical; $49 \%$ said they might be interested in pursuing a career in technology; $70 \%$ participated in community service or volunteer work, and $90 \%$ of children 
between ages 5 and 17 used computers. Teens spent more time online using the internet than watching television; $16 \%$ are shareholders in the stock market; $94 \%$ use the internet for school-related research, and $24 \%$ have created their own web pages. Another survey showed that millennial use of information and communications technology reached to the youngest ages. The largest group of new users of the internet during the period 2000-2002 were 2-5 year olds (NETP, 2005).

The USA's policy makers paid attention to their students' opinions and recognized that they had to accommodate them in the upcoming plans.

NETP 2005 was titled "Toward a new golden generation age in American education". The third educational technology plan in the USA has seven major action steps, namely they were: strengthen leadership, consider innovative budget in, improve teacher training, support e-learning and virtual schools, encourage broadband access, move toward digital content and integrate data systems.

The plan reemphasized the ICT infrastructure, but it was notable that this plan did not identify recommendations about connecting schools with the internet or classrooms with the internet, because it had already equipped the schools with computers. However, the plan recognized that the use of technology had not been shaped, and providing hardware for the schools without enough training in its use would not benefit the educational process in the USA. This study notes that the specific innovative parts in this plan were influenced by the students' survey, and students were encouraged to participate in the up-coming plans. Furthermore, the plan also considered innovative budgeting and made a specific allocation from the spending budget to meet the technology needs. Training the teachers, students and administrators on how to raise their performance based on the technology, was at the core, but this was a natural evolution from the second plan.

After 2005, China witnessed the widespread release of educational technology for all citizens: For instance: the 2006-2020 National ICT Development Strategy stressed educational technology as a means of promoting lifelong learning, and creating an information society. The plan also emphasized the development of various ICT resources, the utilization of network media, and the need to bridge the digital divide. The Eleventh Five-Year Plan for National Education Development emphasized establishing a "learning community" by speeding up the development of the modern education system and promoting the modernization of education through educational technology. Indeed, educational technology for all and learning community was mentioned by name for the first time after 2005.

China initiated several policies and projects to support the previous educational technology policies. It was seeking for fairness and equity and the quality of educational technology in the whole country enjoyed specific attention from the Chinese policy makers. However, China's level of economic development varies from province to province. In educational policy, after 2005, there were specific educational technology policies and initiatives for rural and underdeveloped provinces in China, like the Notification of 2004-2005 Modern Distance Education Project Implementation Plan of Primary and Secondary Schools in Rural Areas, the National Teacher Training 2009 programme, and the Remote Central and Western Rural Compulsory Education School Teachers 2009 Training Programme.

In November 2010, the USA Department of Education promulgated NETP2010, known as a "Model of Learning Powered by Technology". The plan developed based on five main areas; learning, assessment, teaching infrastructure productivity.

NETP 2010 set out its aims in new way. For example, in term of teaching: the previous plans supported the traditional classrooms and traditional learning which used textbooks and depended on the relationship between individual educators and their students. This was not set out as such in any formal policy of the USA's previous plans, but the way of teaching and learning supported traditional classroom praxis. In NETP 2010, technology and students are in the centre of learning process, so the plan's aims support technology-based learning in that there are no limits for the learning community's virtual reality, no limits to accessing the digital learning resources 24 hours a day, 7 days a week, and no limits for the place of learning which can take place anywhere: in school, at home or through portable devices in other places. The plan also makes several recommendations to achieve each aim of the five main aims individually. NETP 2010 seeks to achieve the maximum quality in American education by focusing on the productivity of the learners individually. Policy makers in the USA have reemphasized the educational technology policies that will serve as a crucial factor in their ambition to continue leading the global economy.

In March 2012 China developed its first separated ICT Education Development Long-term Plan which divided into four parts: 
- Overall of Strategy: containing three titles: Status and Challenges, Ideology Guiding, Work principles and Development Goals.

- Development of Tasks: narrow the digital division of basic education and promote the quality of education resources sharing, accelerate vocational education technology and support high-quality skills , promote the integration of information technology with higher education and support innovation and talent training, support the public service platform of continuing education construction and improve the system of lifelong education, integration of information resources and improve the level of modernization of education management, build public support environment of information technology to enhance the capacity and level of public services, strengthen the building and enhance the ability of information technology applications \& innovative institutional mechanisms to achieve sustainable development of information technology in education.

- The quality digital educational resources construction and sharing.

- Safeguard Measures: Strengthen organizational leadership; improve policies and regulations, good technical services and Implementation.

The newest Chinese plan recognized that integrating ICT in Chinese education still faces many difficulties and challenges. The important role of ICT in the educational policy to accelerate the development of ICT infrastructure has not yet been understood; institutional mechanisms have not yet been formed, high quality of infrastructure is not available for all; an effective mechanism for the digital educational resources sharing has not yet been completed; there is a decrease in high-quality education resources; and an integrated education management information system has not yet been formed. However, the policy assumes also, that by the year 2020, each student will have access to an ICT study infrastructure learning-based social system supported by ICT platforms, and will implement broadband coverage for all districts and schools. The plan also emphasizes improving the level of ICT for educational administration and increasing the level of integration between ICT and educational development. In general, China's plan aims at building an educational technology infrastructure close to the developed countries by 2020 .

\subsection{Educational Technology Infrastructure in USA and China 1996-2012}

Infrastructure includes people, processes, learning resources, policies, and sustainable models for continuous improvement in addition to broadband connectivity, servers, software, management systems, and administration tools (NETP, 2010). The study shows the development of the physical hardware infrastructure and focuses on two factors have been repeatedly mentioned in the reports: "schools connected to the internet and number of computers per students". The study found that the USA has annual reports showing the growth of hardware infrastructure, while the numbers in China are available periodically; however, the tables below show the development of the hardware infrastructure in both China and the USA. The numbers shown in the tables below were processed according to the nearest period, i.e. Chinese infrastructure data by 1999 written as 2000 in the table, 2002 data were processed as 2005 in the table. But the data of 2008 and 2011 in the two tables were not altered.

Table 3. General indicators about educational technology infrastructure in USA

\begin{tabular}{cccc}
\hline & & \multicolumn{2}{c}{ Hardware Infrastructure } \\
\cline { 3 - 4 } Year & K12 students total & Computer per students ratio & Percentage of schools connected to the Internet \\
\hline 1995 & 44840000 & No Data & $8 \%$ \\
2000 & 46857000 & $11.1 \%$ & $95 \%$ \\
2005 & 49113000 & $20 \%$ & $100 \%$ \\
2008 & 49266000 & $33.3 \%$ & $100 \%$ \\
2011 & 49361000 & No Data & $100 \%$ \\
\hline
\end{tabular}

Source: Data collected from http://www.usgovernmentspending.com/, National Center for Education Statistics(NCES)-Department of Education USA, Digest of Education Statistics2012- page 71 (edition of Dec 2013-) (NCES1998) (NCES2000) (NCES2003) 
Table 4. General indicators about educational technology infrastructure in China

\begin{tabular}{cccc}
\hline & & \multicolumn{2}{c}{ Hardware Infrastructure } \\
\cline { 3 - 4 } Year & K12 students total & Computer per students ratio & Percentage of schools connected to the Internet \\
\hline 1995 & 244150839 & No Data & No Data \\
2000 & 282292030 & $0.8 \%$ & $0.5 \%$ \\
2005 & 286878680 & $2 \%$ & $1.8 \%$ \\
2008 & 272353282 & $5.3 \%$ & $55 \%$ \\
2011 & 265878383 & $7.7 \%$ & No Data \\
\hline
\end{tabular}

Source: Data collected from: 2012, National Bureau of Statistics of China, Ministry of Education of China Website.

By 1995, the total number of USA's students was 44.84 million and Chinese students were 244.15 million, but there is no data about the number of computer per students. This may was about $1 \%$, because in the first plan it was mentioned that only $4 \%$ of USA's schools have computers for every five students; no statistics are available for China. By the end of the first plan in the USA, the ratio of public schools with internet access reached $95 \%$ and the ratio of the instructional rooms with internet access was 63\%. Also in 1999, the ratio of students per computers was 9:1 while in China the ratio was 121:1, accounting for only $0.8 \%$ of Chinese students. The numbers of schools connected to the internet about 3,000 schools and accounted for $0.5 \%$ of all Chinese primary and secondary schools. However, between the years 2000-2011; China had made tremendous efforts toward establishing the educational technology infrastructure, i.e. the proportion number of students per computer moved from 121:1 by 1999 to $13: 1$ by 2011. The percentage of schools connected the internet had increased from $0.5 \%$ to $55 \%$ of all Chinese public schools by 2008 .

\subsection{Educational Technology Standards in the USA and China 1996-2012}

The USA National Educational Technology Standards (NETS), also known as International Standards for Technology in Education (ISTE), were proposed as "Educational Technology Standards for Students" in the first version in 1998. The first version of USA Standards was proposed for teachers in the year 2000, followed by the first version of the USA standards for administrators in the year 2002. Even though NETS are not governmental publications in the USA they have been widely adopted at a national level; for instance: as ISTE website NETS are adopted at the grassroots and national levels, educators from individual schools up to Ministries of Education are localizing the ISTE Standards to fit the needs of students. Roblyer (2003) found that the standards have been adopted in 41 of the 50 states. The ISTE for Teachers 2008 presented standards for pre-service teachers and are aligned with National Council for the Accreditation of Teacher Education (NCATE) standards (Friedman, Bolick, Berson, \& Porfeli, 2009). In the USA's newest plan (NETP, 2010) there is a clear reference to the ISTE standards for students.

The year 2004 witnessed the emergence of Standards of Educational Technology of China (SETC) that were proposed by the China Association for Educational Technology. CAET is a national organization approved by the MOE. The SETC are for the people who are involved in the educational process (students, teachers, educational administrators and coaches) (CAET, 2004).

Educational Technology standards in China are also not governmental policy, but they have a wide adoption at the national level. According to Liu, Lv, and Kang (2010), the China Association for Educational Technology (CAET) is the largest civil organization for educational technology in China and promotes the development of the field of educational technology. There are 22 division committees, covering many schools, universities or institutions in the four sectors of higher education, basic education, vocational education and adult education. There are 102 group memberships at provincial or ministry level, and several thousand members at different levels. The Secretariat is located within the National Center for Educational Technology. The Association holds an annual conference, undertakes projects in national and educational ministry level and organizes experimental schools from provinces and cities to participate in the projects. It also formulates the standards for educational technology, publishes books, sponsors the Journal of Modern Educational Technology and develops international communications (Liu et al., 2010).

In order to improve the applicability of the standards scientifically, Chinese experts have studied the relevant education technology standards particularly, in both Western countries and related national research. The relevant western countries were the USA and the UK and the standards comparing were National Educational Technology Standards for Teachers (NETS.T), National Educational Technology Standards for Students(NETS.S), National 
Educational Technology Standards for Administrators (NETS.A), Association for Educational Communications and Technology (AECT), the project of educational communications and instructional technologies (ECIT) accreditation standards; ICT standards for UK Teachers, British teachers' professional development standards and professional standards for the headmasters of UK schools. At the national level, experts have paid attention to research on related areas, i.e. the educational technology ability survey for primary and secondary school teachers by Wang Yin, "Performance Standards of Information Technology Teachers" by Zhang Jianwei, and other Chinese scholars' research $(\mathrm{He}, 2005)$.

SETC have been devised for students, teachers, educational administrators and professionals of educational technology; for students, in terms of technology literacy in school, while for teachers, administrators and professionals of educational technology, in terms of technology literacy for all persons involved in educational process. As a general rule, SETC assumes that implementation of the students' standards will promote their growth to meet the needs of social development in the 21 st century and protect them from the external effects, while the implementation will improve the skills of teachers, educational administrators and the quality of coaches, and promote the teachers' professional development. These standards can be used for teachers, educational administrators, educational technology coaches who are involved in the teaching process.

Briefly, educational technology standards in both countries present guidelines for evaluating the skills and knowledge of any one of people who have a direct involvement in the educational process to support $21^{\text {st }}$ century learning needs by implementing and integrating technology in the education process. However, until the year 2004, ISTE had only been developed for students, teachers, and administrators, while the SETC addressed students, teachers, administrators, and coaches. ISTE for students was revised in 2007, and ISTE for teachers was revised in 2008, and ISTE for administrators was revised in 2009.

In 2011, ISTE was amended to include Educational Technology Standards for coaches and computer science educators.

\section{Conclusion}

By using a historical review of the policies achievement, the study concluded that educational technology policies in China were enhanced by the USA experiences. While Chinese national projects in educational technology have stressed by the USA's revised educational technology policies.

Since early 1990, USA has paid specific attention to educational technology policies, and in 1996 the first educational technology plan was promulgated. Both countries policies emphasized that educational technology has a direct impact on the growth of economy.

Historical approach shows that policies in the USA moved from addressing the critical needs for technology literacy to assessing the outcomes of students individually by implementing a technology-based learning model.

In Chinese landscape the situation moved from traditional technology used in education in the early 1990 such as slides, projectors, films, and radio, to initiate modern ICT in policies by the end of 1996.

The study found that China did not have specific separate plans for educational technology before 2012, so the educational technology policies were sometimes only part of the general country plan, Chinese five years plans or Ministry of Education plans and policies, and often had a clear reference in the country plan for ICT. 2012 plan for ICT in education with assumption that it will build an educational infrastructure on par with the developed countries by 2020 .

In terms of The development of equipping the USA and Chinese schools with the ICT hardware infrastructure, despite the huge number of Chinese students compared to the number of USA students over the last two decades, the percentage of computers per students moved from 121:1 to13:1 by the year 2011, while the percentage of schools connected to the internet moved from $0.5 \%$ to $55 \%$. On the other hand, in the USA computers per students were 3:1 with all public schools connected to the internet.

Finally, Chinese scholars themselves indicated the Standards of Educational Technology of (China SETC) are set of comparable standards have developed based on the USA and UK experiences in the field.

\section{References}

Anderson, C. A., Gentile, D. A., \& Buckley, K. E. (2007). Violent video game effects on children and adolescents: Theory, research and public policy. http://dx.doi.org/10.1093/acprof:oso/9780195309836.001.0001

Bereday, G. Z. F. (1964). Comparative method in education. Austin: Holt, Rinehart and Winston.

Bray, M. (2007). Actors and purposes in comparative education. Comparative Education Research Approaches 
and Method, 19, 15-38. http://dx.doi.org/10.1007/978-1-4020-6189-9_1

Bray, M., \& Borevskaya, N. (2001). Financing education in transitional societies: Lessons from Russia and China'. Comparative Education, 37(3), 345-365. http://dx.doi.org/10.1080/03050060120067820

Bray, M., \& Qin, G. (2001). Comparative education in greater China: Contexts, characteristics, contrasts and contributions. Comparative Education, 37(4), 451-473. http://dx.doi.org/10.1080/03050060120091256

China Association of Educational Technology (CAET). (2004). Standards of Educational Technology of China's Education Technology Plan. Beijing: MOE.

Department of Education USA. (1996). National Educational Technology Plan.

Department of Education USA. (2000). National Educational Technology Plan.

Department of Education USA. (2005). National Educational Technology Plan.

Department of Education USA. (2010). National Educational Technology Plan.

E-Education Construction and Application Research Group. (2010). China. Beijing: Higher Education Press.

Fluckiger, F. (1995). From world wide web to information superhighway. IENC6 Conference, Tel Aviv.

Friedman, A., Bolick, C., Berson, M., \& Porfeli, E. (2009). National educational technology standards and technology beliefs and practices of social studiesfaculty: Results from a seven-year longitudinal study'. Contemporary Issues in Technology and Teacher Education, 9(4), 476-487.

He, K. K. (2005). National Educational Technology Standards for Chinese Teachers. Chinese Journal Education informatization construction, 12(4), 37-44.

Liu, M., Lv, J., \& Kang, C. (2010). Educational technology in China. British Journal of Educational Technology, 41, 541-548.

National Center for Educational Statistics. (2000). Digest of Education Statistics.USA.

National Center for Educational Statistics. (2003). Digest of Education Statistics. USA.

National Center for Educational Statistics. (2012). Digest of Education Statistics. USA.

Roblyer, M. D. (2003). Getting our Nets Worth. The Role of ISTE's National Educational Technology Standards. Learning and Leading with Technology, 30(8), 6-13.

Yumin, X., \& Ellen, B. M. (2011). Education technology as a catalyst for education development in China: Policy perspective, the impact and transformation of education policy in China. Emerald Group Publishing Limited, Howard House, USA.

Zhang, J. W. (2005). Development of ICT Education Policy in China. Journal of Electrifying Education of China, 11(5), 31-34.

Zou, L. (2011). The history of 25 years of e-Education. Retrieved from http://www.jspxedu.cn/html/xiaochangzhichuang/lingdaoli/xinxihualingdaol/2011/0117/11964.html\#

\section{Copyrights}

Copyright for this article is retained by the author(s), with first publication rights granted to the journal.

This is an open-access article distributed under the terms and conditions of the Creative Commons Attribution license (http://creativecommons.org/licenses/by/3.0/). 